\title{
Didactic sequence: a dialetic mechanism for language teching and learning ${ }^{1}$
}

\section{Sequência didática: um mecanismo dialético para ensino e aprendizagem de línguas}

Didiê Ana Ceni Denardi*

Universidade Tecnológica Federal do Paraná (UTFPR)

Pato Branco, Paraná / Brasil

\begin{abstract}
In pre- and in-service mother and additional language courses in Brazil, the concept of the didactic sequence has been largely studied as a theoretical and methodological procedure for language teaching and learning, since it focuses on the work of oral and written texts in a genrebased perspective. This text has the aim of extending this concept, taking into account its dialectic nature. To do so, the article reviews the definition, theoretical choices, characteristics, and modular structure of a didactic sequence, comparing this procedure to the concept of a dialectic methodology of knowledge construction in the classroom, and presents a brief analysis of a didactic sequence plan.
\end{abstract}

KEYWORDS: didactic sequence; dialectic mechanism; teaching and learning.

RESUMO: Em cursos de formação inicial e contínua de professores de línguas materna e adicional no Brasil, o conceito de sequência didática tem sido amplamente estudado como um procedimento teórico e metodológico para o ensino e a aprendizagem de línguas, uma vez que se foca no trabalho com textos orais e escritos numa perspectiva de gêneros textuais. Este texto tem o propósito de estender esse conceito considerando sua natureza dialética. Para isso, o artigo apresenta uma releitura da definição, escolhas teóricas, características e estrutura modular da sequência didática, comparando esse procedimento com o conceito de metodologia dialética de construção de conhecimento em sala de aula, e apresenta uma breve análise de um planejamento de uma sequência didática.

PALAVRAS-CHAVE: sequência didática; mecanismo dialético; ensino e aprendizagem.

\footnotetext{
* didiedenardi@gmail.com

${ }^{1}$ This article is part of a doctoral research project carried out by the Post-Graduate Program in English of Universidade Federal de Santa Catarina (UFSC), which resulted in the dissertation entitled Flying together towards EFL teacher development as language learners and professionals through genre writing supervised by Professor Gloria Gil (UFSC) and co-supervised by Professor Vera Lúcia Lopes Cristovão (UEL/PR).
} 


\section{Introduction}

In pre- and in-service mother and additional language courses in Brazil, the concept of the didactic sequence (DOLZ; SCHNEUWLY, 2004; DOLZ; NOVERRAZ; SCHNEUWLY, 2004; SCHNEUWLY; DOLZ, 1999) has been largely studied as a theoretical and methodological procedure for mother and additional language ${ }^{2}$ teaching and learning (for instance, MACHADO, 1997; 2004; CRISTOVÃO et al., 2006; CRISTOVÃO, 2008 and followers), since it focuses on the work of oral and written texts from a genre based perspective. The Didactic Sequence (DS) is also regarded as an instrument of teacher development (DENARDI, 2009) because it can contribute to the teacher's knowledge-based construction (RICHARDS, 1998), thus developing the teacher's contextual, linguistic, and pedagogical knowledge dimensions.

Taking into account the importance of planning a DS to be applied in language classrooms for the enhancement of language teaching and learning processes, this text aims to review and extend the concept of DS by viewing it as a dialectic mechanism for teaching and learning. To do so, the article reviews the definition, theoretical choices, characteristics, and structure of a DS; compares this procedure to the concept of a dialectic methodology of knowledge construction in the classroom (VASCONCELLOS, 2002); and presents, as an example, a brief analysis of a DS plan for the genre advice letter, built by a group of public school teachers and guided by the author of the present text in an English teacher education course in the Southwest Paraná in 2007. Although the DS was planned in 2007, it was chosen to be briefly analyzed here because of its context of production and authenticity.

\section{Reviewing the concept of the Didactic Sequence}

According to the researchers from the group of Didacticism of Languages at UNIGE-Geneva/Switzerland (DOLZ; SCHENEUWLY, 2004; DOLZ; NOVERRAZ; SCHNEUWLY, 2004), who follows the methodological theoretical perspective of Sociodiscursive Interactionism

\footnotetext{
${ }^{2}$ Recently, some Brazilian applied linguistics have advocated the use of the term 'additional language' instead of 'foreign' or 'second language' in order to avoid the prejudice that exists towards learners of English who cannot speak like natives. Therefore, English should be presented and taught as a language to be added to one's linguistic repertoire (SARACENI, 2009, p. 184).
} 
(SDI) (BRONCKART, 2003), a DS refers to a set of classroom planned activities that aims to construct oral and written knowledge and focuses on a specific genre. Dolz and Schneuwly (2004, p. 51) define a didactic sequence as:

.... sequence of teaching modules, conjointly organized to improve a given language practice. Didactic sequences establish the first relationship between a project of appropriation of a language practice, and the instruments that facilitate this appropriation. From this perspective, they intend to confront learners with the historically constructed language practices, namely, textual genres, so that learners are given an opportunity to reconstruct these practices, and consequently, appropriate them [authors' emphasis, my translation ${ }^{3}$.

Thus, since a DS consists of the planning of units and activities on genre-based teaching, mother and additional language teachers may take it as an important theoretical-methodological instrument for English language teaching and learning.

For the aforementioned authors, the learners' reconstruction of "historically constructed language practices" [my translation 4 or "genres" (p. 51) occurs through three interrelated factors, which I will present as follows.

Before mentioning the three main factors, it is important to point out that language practices are socially and historically developed, and are materialized in "forms of genres". Therefore, genres can be seen as instruments of mediation to the teaching of textuality, that is, micro and macro text structures. Based on this view and metaphorically speaking, genre can be used as a (mega) instrument (DOLZ; SCHNEUWLY, 2004, p. 52) to act in language classroom situations. Corroborating this view, Machado (2004)

\footnotetext{
3 ... uma seqüência de módulos de ensino, organizados conjuntamente para melhorar uma determinada prática de linguagem. As seqüências didáticas instauram uma primeira relação entre um projeto de apropriação de uma prática de linguagem e os instrumentos que facilitam essa apropriação. Desse ponto de vista, elas buscam confrontar os alunos com práticas de linguagem historicamente construídas, os gêneros textuais, para lhes dar a possibilidade de reconstruí-las e delas se apropriarem (DOLZ; SCHNEUWLY, 2004, p. 51 / authors' emphasis).

4 “...práticas de linguagem construídas historicamente...” (DOLZ; SCHNEUWLY, 2004, p. 5).
} 
states that genre development is an essential tool for socialization, since it makes it possible for individuals to take part in different human language activities.

The first factor refers to the Characteristics of Language Practices, or in Bakhtin's (2004) perspective Characteristics of Discursive Genre, comprised of thematic content (theme), verbal style (speaker/writer's point of view and values, for example), and composition (textual structure that belongs to a specific genre). Dolz and Schneuwly (2004) state that this is the basis through which to organize activities required for genre teaching.

The second, Language Capacities, refers to the abilities learners should have to understand or produce a specific genre in a specific situation of interaction. These abilities refer to: action, discursive, discursive-linguistic, and signification. ${ }^{5}$ I will review them all in subsection 1.1 below.

Finally, the third, Teaching Strategies, refers to some teachers' interventionist strategies, which are used in educational contexts to foster both the comprehension of a certain genre and the comprehension of the communicative situation in which the genre takes part, as well as the strategies to be used in order to improve genre production by the students.

Moreover, Dolz, Noverraz and Schneuwly (2004) highlight some important theoretical choices that should be taken into account when the procedure of the DS is to be put into practice:

1. pedagogical choices: represent a possibility of formative evaluation; motivate students to produce oral and written texts; open space for students to construct knowledge about the language capacities and genres by means of different activities and instruments.

2. psychological choices: the procedure of a DS aims to enhance students' text production, focusing on the representation of a communicative situation, content knowledge, and text organization, and to make them aware of their own language behavior. To accomplish that, different language instruments and activities are provided to students, such as rules to re-write a text and to check text content knowledge, and specific elements/forms to write argumentations etc.

3. linguistic choices: linguistic elements are used to guide students to produce texts and discourses, which, in turn, are the object of the procedure of a DS in terms of the teaching of listening, reading, speaking, and writing.

\footnotetext{
${ }^{5}$ Recently, Cristovão and Stutz coined the capacity of signification.
} 
4. general finalities: some main objectives of DSs include: a) to prepare students to communicate, orally and in writing, in different situations, by means of efficient instruments; b) to make students aware of their own language, or an additional language, and how they can act with language, by means of formative and summative evaluations; c) to make students build a representation of written and oral activities in complex communicative situations as a result of a classroom task.

\subsection{Language capacities as an interrelated language system}

From an SDI point of view, language capacities are defined as a set of operations that allows the accomplishment of a specific language action. Language, in turn, is seen by Vygotsky (1986) as a tool that mediates knowledge construction, that is, spontaneous knowledge is turned into scientific knowledge by means of language. Dolz and Schneuwly (2004) distinguish three types of language capacities in which learners should have to understand or produce a specific genre in a particular situation of interaction, which are described below:

a) action capacity refers to the genre itself. According to Bronckart (2003, p. 99) language action can be understood at both sociological and psychological levels. In the first level, it is possible to analyze the parameters of the context in which the action takes place, whereas in the second, it is possible to identify the values the agent/writer attributes to the elements of the text's context of production, as well as to its content. In other words, action capacity involves the understanding of the relation between thematic content and the text's context of production, as well as the writer's intentions or purposes. Thus, action capacity constitutes and is determined by the: a) parameters of context of production and reading: physical and socio-subjective aspects of these contexts (interlocutors, place, and time determiners); b) content of the action language: what is said; c) purpose of the communicative language action: the reasons to say what is to be said, and the expectations of the saying;

b) discursive capacity refers to the form of language action is organized, involving the understanding of the textual macro-structure, types of discourse, ${ }^{6}$ and types of sequence ${ }^{7}$ used during language action;

\footnotetext{
${ }^{6}$ Based on Habermas' discursive worlds, Bronckart (2003) defines four types of discourse: interactive discourse, theoretical discourse, interactive report and narration.

${ }^{7}$ Bronckart (2003), based on Jean Michel Adam, classifies six types of textual sequences as narrative, descriptive, injunctive, argumentative, explicative and dialogal.
} 
c) discursive linguistic capacity involves the understanding of an adequate use of discursive linguistic units, or any linguistic or semantic language resource available in a specific language system, which contributes to making language action real in terms of style and form. More specifically, in relation to textual analysis, the elements of the discursivelinguistic language capacity refer to textual and enunciative mechanisms. For example, cohesive devices and modalizers, among others, in order to create the whole meaning of the text.

In a recent study, Cristovão and Stutz (2011, p. 22) reviewed the categories of analysis of each language capacity, as well coined a fourth language capacity, the signification capacity. As its name implies, its main objective is to extract and to "build sense (of the text) based on representations and/or knowledge about social practices" [my translation and addition between parenthesis $\left.{ }^{8}\right]$. Therefore, such capacity comprehends the relation between text and the different contexts of social practices that are: "ideological, historical, sociocultural, economic, etc." [my translation']. In other words, by means of the signification capacity, the student can understand the relationship between texts and the authors' forms of being, thinking, acting, and feeling, as well as construct a point of view concerning these relationships (p. 23). Consequently, by means of work conducted with this capacity, the teacher can guide the student towards developing criticism of local and global events, situations etc that surround him/her.

Yet, in relation to language capacities, Cristovão (2007) compares the way language capacities function in a text as a set of toothed wheels working together in a system of activities within a system of genres. This comparison makes it possible to understand the intrinsic system of language capacities, that is, one capacity contributes to the functioning of the other and viceversa. However, it is important to highlight that for the specific purposes of teaching and text analysis, language capacities and their constitutive elements can first be split and discretely analyzed, and should subsequently be observed as a whole, since in an empirical language situation they are intrinsically related and linked.

\footnotetext{
8 “...construir sentido mediante representações e/ou conhecimentos sobre práticas sociais...” (CRISTOVÃO; STUTZ, 2011, p.22).

9 “ideológico, histórico, sociocultural, econômico, etc” (CRISTOVÃO; STUTZ, 2011,p.22).
} 
In short, a DS, aimed at the teaching of genres, can be seen as an interventionist classroom practice in which teachers can use some specific strategies in order to guide students to understand complex communicative events and activities. To accomplish this, teachers have to de-compound the events/activities and work, one by one, with the problems students face when they study a specific genre. This set of activities, in turn, guides teachers' work to the object of knowledge: the genre. Moreover, through the application of DSs in language classrooms, it is possible to develop the learners' linguistic and discursive-linguistic capacities to work with texts that belong to particular genres (CRISTOVÃO, 2002). In addition, by means of the action and signification capacities, students can develop a critical understanding of things, situations, and events, as well as expand their world knowledge.

As seen above, the construction or re-construction of knowledge about genres can occur through the teaching of genre characteristics using a DS procedure, which takes into account students' language capacities and difficulties concerning the genre to be studied. In this regard, Dolz, Noverraz and Schneuwly (2004) emphasize that the purpose of a DS lies in promoting students' access to new and difficult genres in order to master language practices. Therefore, school work should be done with genres that students do not master or have insufficient knowledge about; with genres of difficult access by the majority of students; and with public genres. In other words, the authors seem to refer to the apparently common genres that circulate in specific spheres of communication. For example, in school context: work with summaries, oral exposition, debate etc.

With those purposes in mind, a DS procedure was first designed, specifically for the teaching of writing. However, as already stated, a DS corresponds to a set of organized school activities to teach oral and written text genres. A DS for writing consists of a modular structure. This structure starts by the presentation of a communicative situation; followed by the initial production; the modules constituted by re-writings and additional information/ideas; and the final production. The initial production functions as a diagnosis of learners' capacities and necessities related to the studied genre. That is, from the first production, teachers can have access to what students already know about the genre and then build or propose activities so that they can develop new knowledge. Thus, the first production refers to the starting point of formative evaluation. During the process, teachers can build, or co-construct together with the students, 
some checklists which can be seen as dialogic mechanisms teachers use to guide students to master the genre they are learning or as a tool teachers and students themselves can use to evaluate text production. At the end of the writing task, teachers can compare the first and last production to check learners' language development in relation to the four language capacities and the knowledge about the specific genre as a whole.

In the following section, I will report on an analysis carried out by comparing each step of a DS to the concept of a dialectic methodology of knowledge construction in the classroom (VASCONCELLOS, 2002).

\section{The DS as a dialectic mechanism for mother and additional language teaching and learning}

Based on the dialectic theory of knowledge construction, which consists of three basic phases of knowledge construction, called syncretism, analysis and synthesis. Vasconcellos (2002) proposes a dialectic methodology of knowledge construction in the classroom. This methodology also encompasses three main phases:

a) mobilization to knowledge construction: in this phase the teacher should challenge or guide students to construct meaning of the object of study, that is, this is the moment to learn about the object of study;

b) knowledge construction: in this second phase, the teacher should guide students to establish internal and external relations to the object of study in order to learn it in its essence; thus, it is the moment of analysis of the object of study;

c) elaboration and expression of the knowledge synthesis: here the teacher should guide students to systematize the constructed knowledge and express it in a concrete form, which can be summarized as the moment to systematize knowledge.

By comparing these three phases of knowledge construction in the classroom to the modular structure of a DS, it is possible to say that the first step of a DS refers to the presentation of a communicative situation. It serves to both show students that a writing project will be carried out in the classroom, which will result in a final text, as well as to prepare them to write their first version of a specific genre, which will be retaken in the modules. This first step of a DS can be related to the phase of mobilization to knowledge construction in a dialectic classroom methodology (VASCONCELLOS, 2002), 
because it helps students to link the content to be learned with their language practices by making content meaningful and challenging them to build a kind of representation of the communicative situation of the activity. In other words, the presentation explicitly confronts students with a problem of communication by challenging them to act in a situation in which they should produce an oral or written text about something meaningful for them.

The initial production can be characterized as a first practice with the objective of study, that is, what is called the praxis in a dialectic methodology. This first practice requires students to act on the object of study - a text that belongs to a specific genre - in order to make knowledge articulation possible within the students' social practices. As a result, a DS allows students and the teacher to formulate a kind of diagnosis about students' capacities and difficulties within the specific genre. Particularly, it allows the teacher to initiate the process of formative evaluation. In other words, the teacher can have a clear view of students' knowledge about the language, thematic content and genre organization, and then decide from what point to start the teaching process and how far to deepen it. Thus, knowledge is constructed from what dialectic methodology calls a critical view of reality, since the initial production makes it possible to have a diagnosis of students' capacities and necessities and their determinations in relation to the genre that is studied. In other words, the process departs from students' syncretism about the object of study to the construction of a qualitatively higher level of knowledge, that is to install a movement of rupture with the syncretic view of knowledge the students have, as well as a movement of continuity with the new elements/knowledge explicitly explained by the teacher to be applied in students' written or oral productions. This movement of knowledge construction starts in the initial production, but it should be accomplished in all modules of a DS.

The problems observed by means of the analysis of initial oral or written productions are worked on one by one in the modules of a DS. Different activities, new readings and research about thematic content, grammar exercises, re-writings, text analysis related to the language capacities and checklists with elements that constitute the specific genre are some of the pedagogical instruments used in the modules. Related to text analysis, texts are also analyzed in terms of contexts of production and textuality that involves the process of knowledge construction from contextual relations 
- historicism - in which physical and socio-subjective parameters of text construction are analyzed and confronted with the socio-historical current situation. Another aspect to be compared between the procedure of a DS and the dialectic methodology refers to the movement from its complex part to simple ones in the beginning, and then from the simple ones, by means of the study of language capacities, to the complex again - the final text of a DS. This dynamic movement represents the rupture with the students' view before the study of the genre to the knowledge they could build during the process, giving continuity or being able to study and know other genres. The final text represents the synthesis of the process, as seen below.

As a final stage of a DS, the finalproduction provides students with the opportunity to use the knowledge constructed during the modules. This construction presupposes that students can make important relations inside the complexity of the content knowledge/language capacities they were exposed to during the whole development of a DS. In this perspective, the whole and the parts are articulated by means of internal connections of the elements that determine the final text. Therefore, it represents the synthesis of the whole process. Moreover, final production allows teachers and students to observe students' development/improvement in text production, and thus serves as an instrument for summative evaluation. In turn, the entire process of students' text production can be observed and checked as a process of writing development, which subsequently constitutes formative evaluation.

In the next section, as an illustration, I will present a brief analysis of a DS plan for the "advice letter" genre.

\section{Analysis of a DS plan applied to the Advice Letter genre}

Before starting the analysis, it is important to mention something about the DS plan's context of production. The DS plan, chosen to be briefly analyzed here, was built by a group of Basic Education public school teachers in a 60 hour/class course of ongoing education in a Southwestern town in Paraná in 2007. In the course, 10 participant teachers were taught about Didactic Transposition (DT), which in turn involves the processes of building a Didactic Model (DM) and a Didactic Sequence (DS).

The teachers were provided with some theoretical explanations about the whole process of DT and, later on, with some Didactic Models of some genres to study, such as: biography, autobiography, comic strips, letter to the editor, advice letter, fairy tale etc. They were asked to organize themselves in 
small groups of 3 or 4 , and to choose one of those genres to study. Teachers organized themselves into 3 groups: 1 group chose the advice letter genre, while the 2 remaining groups chose the fairy tale genre. With the chosen DMs in hand, participants could build their DS plans to be taught to their students in real English classes.

Due to the spatial constraints, as well as our focus in this article - to discuss DS as a dialectic mechanism of knowledge construction in the classroom - I will only present part of the analysis of a DS plan for the writing of an advice letter: ${ }^{10}$ the DS structure analysis. It attempts to show the interrelation/articulation between the activities related to language capacities and the dialectic process of knowledge construction in the classroom.

A DS plan of textual written production of an advice letter is addressed to 14 to 17-year-old students, who attend regular school in Brazil. It proposes that the activity of writing advice letters should be carried out by means of a first production, re-writings and a final production, in which, in between the tasks, students can be guided, by means of the teacher's and peers' orientations on the letters and the use of checklists, to construct knowledge of writing by means of the genre. This can be observed in the table below, in which excerpts related to objectives, as well as classroom procedures and activities, were extracted from the plan ${ }^{11}$ (APPENDIX I) to be analyzed.

For the purpose of analysis, the DS plan is fragmented and shown in Tables 1, 2, 3 and 4 below. All tables present the same introduction, that is: the theme, genre, and general objective of the DS. However, each table presents different procedures and descriptions of activities related to the steps/modules it represents in the DS. Table 1 presents excerpts from the steps of theme presentation, situation presentation and first production.

\footnotetext{
${ }^{10}$ A complete analysis of this mentioned DS plan can be found in the doctoral dissertation "Flying together towards EFL teacher development as language learners through genre writing” (DENARDI, 2009, Chapter VIII). Moreover, providing a description of the context and the process of construction of the DS by a group of public school teachers, the analysis includes aspects related to the a) adequacy between thematic content to objectives, activities and methodological procedures of the DS; b) adequacy between the elements to be taught related to the three language capacities which are proposed in the didactic model (CRISTOVÃO et al., 2006), and c) adequacy to ten guidelines for the teaching of writing in EFL classes proposed in Chapter III of the same dissertation.

${ }^{11}$ See the complete DS plan in APPENDIX 1.
} 


\section{TABLE 1}

Description of procedures and activities related to the presentation of theme, genre, situation and first production

\begin{tabular}{|c|c|}
\hline \multicolumn{2}{|c|}{ THEME: ASKING FOR ADVICE } \\
\hline \multicolumn{2}{|c|}{ DS Plan: Genre Advice Letter. } \\
\hline \multicolumn{2}{|c|}{ General Objective: To ask for a piece of advice and obtain answers. } \\
\hline \multicolumn{2}{|c|}{$\begin{array}{l}\text { Specific objective: To give students the opportunity to perceive that everybody has problems } \\
\text { and conflicts in his/her life and that through the advice letter they can receive help for their own } \\
\text { problems and conflicts. }\end{array}$} \\
\hline Modular Structure & Specific Procedures and Description of Activities \\
\hline $\begin{array}{l}\text { Theme } \\
\text { Presentation and } \\
\text { Warm-up activity }\end{array}$ & $\begin{array}{l}\text { 1-The students will watch and discuss the first scenes of the film "Message } \\
\text { in a Bottle" (Mandoki, 1999), which refers to the production of a personal } \\
\text { letter, which was afterwards published in a newspaper and had a great } \\
\text { repercussion in its local community. Oral questions, about the experience } \\
\text { of receiving letters, as well as questions related to the content/purpose and } \\
\text { the context of the production of the letter from the film, will be asked to } \\
\text { students to guide the oral discussion. }\end{array}$ \\
\hline $\begin{array}{l}\text { Situation } \\
\text { Presentation }\end{array}$ & $\begin{array}{l}\text { 1-The students will be told that they are going to produce an advice letter, } \\
\text { so they should think about some doubts or problems they have, break into } \\
\text { pairs, and discuss them. } \\
\text { 2- The students will also be required to write and address the letter to the } \\
\text { teacher, who will answer it and give the students some advice. }\end{array}$ \\
\hline First Production & $\begin{array}{l}\text { 1-In pairs, the students will be asked to write a letter of advice. } \\
\text { 2- On finishing the task, the students should hand in their first versions to } \\
\text { the teacher. } \\
\text { 3-At home, the teacher can observe the letters in terms of students' } \\
\text { limitations and capacities, related to the three language capacities. }\end{array}$ \\
\hline
\end{tabular}

As seen from Table 1, when the teacher presents students with the theme and the communicative situation of producing an advice letter, $\mathrm{s} /$ he is involving students and mobilizing their previous knowledge about the theme and the object of study, as well as their language capacities. Thus, the teacher performs the first step of dialectic knowledge construction in the class, that is: knowledge mobilization.

In turn, in the first production, the praxis, the teacher requires students to act on the object of study, the writing of an advice letter, expecting to receive a diagnosis about students' capacities and difficulties related to the elements or aspects of the language capacities that belong to the advice letter genre. This leads to the process of formative evaluation. As already explained in this article, the process of knowledge construction departs from students' syncretism about the object of study to produce a qualitatively higher level of knowledge, in a movement of rupture to a movement of continuity 
of knowledge construction, which starts in the initial production and should be accomplished in all modules of a DS.

Table 2 below, shows the description of the work with action capacity and capacity of signification.

TABLE 2

Studying action capacity and capacity of signification

\begin{tabular}{|c|c|}
\hline \multicolumn{2}{|c|}{ THEME: ASKING FOR ADVICE } \\
\hline \multicolumn{2}{|c|}{ DS Plan: Advice Letter Genre } \\
\hline \multicolumn{2}{|c|}{ General Objective: to ask for a piece of advice and obtain answers. } \\
\hline Specific Objective & $\begin{array}{l}\text { To give students the opportunity to perceive that everyone has problems } \\
\text { and conflicts in his/her life and that through the advice letter they can receive } \\
\text { help for their own problems and conflicts. }\end{array}$ \\
\hline Modular Structure & Specific Procedures and Description of Activities \\
\hline $\begin{array}{l}\text { Module 1: Working } \\
\text { on Action Capacity } \\
\text { and Capacity of } \\
\text { Signification: }\end{array}$ & $\begin{array}{l}\text { 1- The authentic letter of advice below will be brought by the teacher to } \\
\text { the class, as a reference text. } \\
\text { Dear Betty, } \\
\text { I have a crush on this popular guy in my school. He's so cute and funny. OK, } \\
\text { so he gave me his phone number on the last day } \\
\text { of school (he saw that a friend of mine wrote that I liked him). But the } \\
\text { problem is that 1) I'm not really popular; 2) He has a girlfriend; 3) I never } \\
\text { had classes with him, so he doesn't really know me; and 4) I'm scared of } \\
\text { calling him I think he'll make fun of me or something. Please, can you help } \\
\text { me? What should I do? Lexy } \\
\text { Source: http://www.beatboxbetty.com/dearbetty/dearbetty/dearbetty.htm } \\
\text { Access on: October } 25^{\text {th }}, 2007 \text {. } \\
\text { 2-Together with the students, the teacher will discuss the thematic content, } \\
\text { production context, other related contexts (family, social, for example) and } \\
\text { the purpose of the reference letter. } \\
\text { 3-While analyzing the reference letter - Lexy's - the teacher and students } \\
\text { together will elaborate a list (the first checklist) of elements related to } \\
\text { action capacity for students to use it to write up their own letters. The list } \\
\text { could contain the addressee's name (teacher's name), the exposition of the } \\
\text { problem, personal conflict or doubts, the asking for help and the name } \\
\text { of the authors at the end of the letter (see the analysis in APPENDIX } 2 \text { ). } \\
\text { 4-The teacher will give back the students their first versions of the letter } \\
\text { and they will rewrite them by means of the collaboratively built checklist. } \\
\text { 5- On finishing the analysis, students will hand the new version of their } \\
\text { letters to the teacher. } \\
\text { 6- At home, the teacher will take notes on his/her notebook, again, about } \\
\text { the students' progress. }\end{array}$ \\
\hline
\end{tabular}

Table 2 shows the teacher's intention to use an authentic advice letter - Lexy's letter $-\mathrm{s} /$ he got from an internet site as a reference text in order to construct knowledge related to the action capacity and capacity 
of signification that are present in advice letters. Next, students will review their first versions of the letters guided by the use of the checklist they constructed collaboratively.

As seen, in the work with action capacity, the teacher continues the process of constructing knowledge by means of making students rewrite their advice letters in a real language communicative action. Or in participants' words: 'Letters will be written with a real purpose, in a social context that is authentic for the students and addressed to the "advisor", that means to the teacher, who will read and answer the letters giving advice" (Participants' report).

Passing to Table 3, there is a description of the work with a global plan and discursive capacity.

TABLE 3

Studying discursive capacity

\begin{tabular}{|l|l|}
\hline \multicolumn{2}{|l|}{ THEME: ASKING FOR ADVICE } \\
\hline DS Plan: Advice Letter Genre \\
\hline General Objective: to ask for a piece of advice and obtain answers \\
\hline Specific Objective & $\begin{array}{l}\text { To provide the students the understanding of the advice letter's internal } \\
\text { structure through the study of the global textual plan }\end{array}$ \\
\hline Modular Structure & Specific Procedures and Description of Activities \\
\hline $\begin{array}{l}\text { Module 2: Working } \\
\text { on the Global Plan and }\end{array}$ & $\begin{array}{l}\text { 1-The teacher will guide students to analyze the reference advice } \\
\text { letter, as well as the students' letters, in terms of internal organization } \\
\text { (initial greeting, problem, advice question, pseudonym, as shown in } \\
\text { APPENDIX 2). } \\
\text { 2- The students and teacher will collaboratively build a checklist of the } \\
\text { moves of the advice letter genre, as shown in procedure number 1 above. } \\
\text { 3- The teacher will hand students another checklist (list of words and } \\
\text { expressions regularly present in some advice letters (Dear../ I'm.../ } \\
\text { Can you help me?/ What should I do? etc), so that they can revise and } \\
\text { rewrite their texts again. } \\
\text { 4-On finishing the analysis, which will be followed by the text rewritings, } \\
\text { students will hand the new version of their letters to the teacher again. } \\
\text { 5- The teacher will again take notes in his/her notebook about the } \\
\text { students' progress. }\end{array}$ \\
\hline
\end{tabular}

As seen in Table 3, the teacher will explore the discursive capacity through the reading comprehension of the reference advice letter and the students' letters (students' letters could be written in Portuguese or in English, depending on the students' knowledge and feelings in relation to the English Language), and of the building of a checklist with the phases/ rhetorical movements of an advice letter. This discursive analysis provides 
students with the understanding of the types of discourse present in the advice letter genre, which are interactive and interactive report, and the structure of the predominant types of sequence, which are descriptive and explicative, although it is not explicitly necessary to mention these terms to the students. Here, again, the knowledge construction of language and the advice letter genre continues to constitute a moment of analysis of the object of study: the advice letter genre, or the analysis phase in the dialectic theory of knowledge construction in the classroom.

Next, Table 4 presents the description of procedures and activities related to discursive-linguistic capacity.

\section{TABLE 4}

Studying discursive-linguistic capacity

\begin{tabular}{|c|c|}
\hline & R ADVICE \\
\hline DS Plan: Advice Lett & r Genre \\
\hline General Objective: to & ask for a piece of advice and obtain answers. \\
\hline Specific Objective & $\begin{array}{l}\text { To make students observe and learn specific vocabulary and some grammar } \\
\text { points in the context of an authentic published advice letter. }\end{array}$ \\
\hline Modular Structure & Specific Procedures and Description of Activities \\
\hline $\begin{array}{l}\text { Module 3: Working } \\
\text { on the Discursive- } \\
\text { linguistic Capacity }\end{array}$ & $\begin{array}{l}\text { 1-The teacher will show students or ask them to search for specific vocabulary } \\
\text { and expressions -in the reference letter (Dear.../I'm.../she's.../scared of.../ } \\
\text { call.../Can you help me? /What should I do?). } \\
\text { 2- Using the reference text again - Lexy's letter - the teacher will show students } \\
\text { the structure of a statement of the problem: Subject pronoun (I, he, she, they) } \\
+ \text { is / have/has + a problem (he's not popular at school / he's already got a } \\
\text { girlfriend / she's afraid of calling him), as well as, show syntactic structures } \\
\text { of an advice requirement with modal verbs 'should' and 'can': Should + I/ } \\
\text { he/she/they +do? (What should I do?), can: Can + you/he/she/they + help } \\
+ \text { me/them/us (Can you help me?). In addition, the teacher can teach other } \\
\text { grammar content, such as subjective and objective pronouns, for example. } \\
\text { 3- The teacher will hand the students the lyrics of the song "Mr. Postman" } \\
\text { (The Carpenters, 1975), since it evokes the activity of writing or receiving a } \\
\text { letter. The lyrics of Mr. Postman show how a person is anxiously waiting for } \\
\text { a postal worker to receive a letter from his/her girl/boyfriend. By means of } \\
\text { pointing to some sentences and syntactic structures in the song and through } \\
\text { the sentences extracted from students' own text productions, the teacher will } \\
\text { assign students some grammar exercises and provide some explanations on } \\
\text { verbs in the present and past tenses, modal verbs (should, can), pronominal } \\
\text { anaphora etc. } \\
\text { 4- The students will revise their letters by means of the checklists that would } \\
\text { have already been built in the classroom or provided by the teacher or even by } \\
\text { using a grammar book. Afterwards, they will rewrite the letters for the third } \\
\text { time. } \\
\text { 5-On finishing the rewritings, the students will hand in the third version of } \\
\text { their letters to the teacher. } \\
\text { 6- The teacher will again take notes in his/her notebook about the students' } \\
\text { progress, as well as address a concept to each student's work. }\end{array}$ \\
\hline
\end{tabular}


As seen in Table 4, in the discursive-linguistic capacity, the teacher will explore vocabulary and grammar structures. Vocabulary will be dealt with by means of the building of a new checklist with expressions related to greetings and to the structure of advice requirement, as can be seen in APPENDIX 2. In turn, cohesion and pronominal anaphora will be explored by means of the lyrics "Mr. Postman" and from examples taken from the students' own productions. It is also possible to focus the study on modalization (verbs "can", "should") by observing some samples extracted from the reference letter and the students' own texts.

Once again, knowledge construction of language continues to constitute a moment of analysis of the object of study - the advice letter genre - alternating the movements of rupture and continuity of a dialectic activity of knowledge construction.

The third version of the students' advice letters will then be taken as a result of the process of the text production of an advice letter, as well as the synthesis of knowledge construction in a dialectic theory of knowledge construction in the classroom.

In sum, we can state, from the objectives and activities of the DS plan, that the language capacities are adequately related. It is also possible to say that orientations and activities of one language capacity/plan can be connected to the other, that is, they can be taught in an articulated way, as recommended by some language didactic scholars (e.g.: CRISTOVÃO, 2007).

Moreover, to guide students to write their advice letters, the teachers develop a teaching plan, which is a DS plan, with some activities to explore the content, the structure and the linguistic elements that constitute the advice letter genre. Therefore, by means of what is established in the plan, students can receive clear orientation to: a) select the type of discourse related to the advice letter genre - 'the interactive report type of discourse'; b) build knowledge about the thematic content to be developed in their texts; c) have a global view of the genre; d) build knowledge about the types of sequence: descriptive and explicative; e) connect words and sentences; e) organize the thematic progression of the text; f) use/learn specific words and the modal verbs 'can' and 'should', among others, as well as conjunctions, personal pronouns, adjectives etc.

Finally, it can be said that the continuous process of writing, revising, redoing or re-writings, together with and the teachers' and peers' feedback, 
which can be observed in the analyzed DS plan, can greatly contribute to students' knowledge and development in the task of writing effective texts. In other words, by means of the application of a DS in English language classrooms, students can mobilize, construct, and produce a synthesis of knowledge about specific thematic content, language and genres.

\section{Some final remarks}

This article aimed to present a review and extend the concept of a DS, viewing it as a dialectic mechanism for teaching and learning language. To accomplish this, I reviewed the definition, theoretical choices, characteristics and structure of a didactic sequence, as well as compared the methodological procedure to the concept of a dialectic methodology of knowledge construction in the classroom (VASCONCELLOS, 2002). In addition, I presented, as an example, a brief analysis of a DS plan for the advice letter genre, which was built by three in-service teachers in a teacher education course in Southwest Paraná (Brazil) in 2007.

Particularly, concerning the comparison of the DS modular structure to the dialectic method of building knowledge in the classroom, it can be said that: a) the first phases of a DS - the situation presentation and first production - can be associated with the movement of knowledge mobilization; b) the modules of teaching can be compared to the movement of knowledge construction from the dialectic method; and c) the final production can be related to the movement of synthesis of knowledge or constructed knowledge.

It is also important to mention that by constructing a DS applied to the advice letter genre (involving the language capacities: action, discursive and discursive-linguistic, signification), teachers were able to realize the values and ideologies that exist in the authentic texts that encompass society, as well as the discursive practices and social relations that constitute human interaction. In other words, through the planning of DSs, teachers can coconstruct educational, social and linguistic types of knowledge, since in the task of planning they must analyze texts and their contexts of production, and then understand their roles in the school and society in which they live. Therefore, by means of this understanding, teachers can help students learn and understand the aspects shown in this study, as well as contribute to their development as citizens, since they will be guided to think critically about the themes, contexts, author's point of view etc., that is, to make sense of the text. 
In conclusion, we assume that the procedure of a DS as a dialectic methodology of knowledge construction in the classroom can challenge, motivate, and guide the teacher's and students' oral and written language knowledge. From a teacher's perspective, developing and applying a DS plan could be understood as a theoretical-methodological and reflexive mechanism for teacher education, since it guides teachers' actions and makes them reflect about different aspects that constitute their linguistic and pedagogical practice, such as context, social aspects, ethics, linguistics etc. On the other hand, from a student's perspective, students can build language practices (reading, writing, listening and speaking practices) and produce intelligible English language, thus communicating and acting in society appropriately and, consequently, successfully.

\section{References}

BAKHTIN, M. M. The problem of genre speech. In: BAKHTIN, M. M. Speech genres and other late essays. Austin: University of Texas Press, 1986. p. 60-102.

BRONCKART, J. P. Atividade de Linguagem, textos e discursos: por um interacionismo sócio-discursivo. 2. ed. São Paulo: EDUC, 2003.

CRISTOVÃO, V. L. L. Modelo didático de gênero como instrumento para formação de professores. In: MEURER, J.L.; MOTTA-ROTH, D. (Org.). Gêneros Textuais. Bauru: EDUSC, 2002. p. 31-73.

CRISTOVÃO, V. L. L. et al. Cartas de pedido de conselho: da descrição de uma prática de linguagem a um objeto de ensino. Linguagem \& Ensino, Pelotas/RS, v.9, n.1, p. 41-76, jan-jun. 2006.

CRISTOVÃO, V. L. L. Modelos didáticos de gêneros: uma abordagem para o ensino de língua estrangeira. Londrina: EDUEL. 2007.

CRISTOVÃO, V. L. L. et al. (Org.). Estudos da linguagem à luz do Interacionismo sociodiscursivo. Londrina: UEL, 2008.

CRISTOVÃO, V. L. L.; STUTZ, L. Sequências didáticas: semelhanças e especificidades no contexto francófono como LI e no contexto brasileiro como LE. In: SZUNDY, P.T.C. Ensino e aprendizagem de línguas no contexto brasileiro. Campinas: Pontes Editores, 2011. p. 17-39.

DENARDI, D.A.C. Flying together towards EFL teacher development as language learners and professionals through genre writing. 2009. 256p. Doctoral Dissertation (Ph.D. in Language and Linguistics Applied to the Teaching of English) - Post-Graduate Program in English Language and Literature, Universidade Federal de Santa Catarina (UFSC), Florianópolis, 2009. 
DOLZ, J.; SCHNEUWLY, B. Gêneros e progressão em expressão oral e escrita: elementos para reflexões sobre uma experiência suíça (francófona). In: SCHNEUWLY, B.; DOLZ, J. (Org.). Gêneros orais e escritos na escola. Trans. Roxane Rojo R., Glaís Sales Cordeiro. Campinas: Mercado de Letras. 2004. p. 41-70.

DOLZ, J.; NOVERRAZ, M.; SCHNEUWLY, B. Seqüências didáticas para o oral e a escrita: apresentação de um procedimento. In: SCHNEUWLY, B.; DOLZ, J. (Org.). Gêneros orais e escritos na escola. Trans. Roxane Rojo R., Glaís Sales Cordeiro. Campinas: Mercado de Letras, 2004. p. 95-128.

MACHADO, A. R. A transposição do conhecimento científico para o contexto de ensino: as necessidades e as dificuldades. In: Seminário sobre critérios de avaliação de livros didáticos $5^{a}$ a $8^{a}$ séries. Brasília: Ministério de Educação e de Desporto, 1997. (mimeografado).

MACHADO, A. R. (Org.). O ensino como trabalho: uma abordagem discursiva. São Paulo: Contexto, 2004.

MACHADO, A. R. A perspectiva sócio-interacionista de Bronckart. In: MEURER, J. L.; BONINI, A.; MOTTA-ROTH, D. (Org.). Gêneros: teorias, métodos, debates. São Paulo: Parábola Editorial, 2005. p. 237-259.

RICHARDS, J. C. The scope of second language teacher education. In: RICHARDS, J. C. (Org.). Beyond Training. Cambridge: Cambridge University Press, 1998. p. 1-48. SCHNEUWLY, B.; DOLZ, J. Os gêneros escolares: das práticas de linguagem aos objetos de ensino. Revista Brasileira de Educaşão, Rio de Janeiro, v. 11, p. 5-16, maio-ago. 1999.

SARACENI, M. Relocating English: towards a new paradigm for English in the world. London: Language and Intercultural Communication v. 9, n. 3, p. 175-186, ago. 2009.

VASCONCELLOS, C. S. Construção do conhecimento em sala de aula. São Paulo: Libertad, 2002.

VYGOTSKY, L. S. Thought and language. Cambridge: MIT Press, 1986.

Data de submissão: 26/02/2016. Data de aprovação: 02/08/2016. 


\section{APPENDIX 01}

\section{Didactic sequence plan: genre advice letter}

$1^{\text {st }}$ production: The teacher $(\ldots)$ will ask students to produce a first written version of their advice letters. In a box, whose decoration alludes to letter writing, the learners will place their advice letters written in Portuguese (...). As the teacher picks up the letters from the box, he/she will analyze the learners' letters one by one to check their background knowledge related to this subject.

\section{Activities:}

The learners, in groups of three, will analyze some advice letters written in Portuguese (...). The teacher will guide learners in order to make them identify the elements of the context of production (situação de produção, autor, destinatário, objetivo, conteúdo, espaço social de produção, momento histórico de produção, meio de veiculação) and the moves of an advice letter (saudação inicial, problema, pedido de conselho, pseudônimo), in Portuguese at first.

The teacher and the learners will build a controlling list with phases from an advice letter writing, considering specifically the language action plan and the discursive plan.

The teacher and students will translate into English some expressions and sentences that express the greetings and some pseudonyms. The teacher will also explain about the structure of a statement of the problem, the structure of an advice requirement etc.

2nd production: The teacher will give back the learners their first version and explain that they are going to read the first version, but they do not have to correct it. Instead, they are supposed to produce a second written version of their advice letter now in English. They will do this through the use of the two controlling lists provided by the teacher: the list of expressions and the list of the moves of an advice letter.

\section{Activities:}

To improve students' textual (coherence / cohesion) and grammatical knowledge (verb tenses, pronouns), the teacher will work with the song "Mr. Postman" (The Carpenters, 1975). Students will break into pairs, and they will be given the lyrics with the verses of the song in jumbled order. While they listen to the song, they are supposed to order it by numbering the verses.

The teacher will provide the translation of the song, but the students will have to match the song verses with their correct meaning. 
The teacher will call the students attention to the verb tenses found in the song, and will pick up some sentences as examples of simple present and simple past.

At this point there will be an explanation about the use of modal verbs 'can/ should' in the context of the advice letter genre. The teacher will also review the pronominal anaphors by using some sentences from the song as examples. Other grammar exercises will be designed in advance and should be implemented during the application of this didactic sequence.

\section{3rd production:}

At this stage, the learners will be given their second production back and the teacher will ask them to write a new version of their advice letter, using the controlling lists as a guide; they will also be asked to check the linguistic elements, such as the verb tenses, the modals, the pronouns, for instance.

\section{Activities:}

With the use of the controlling lists, the learners will be asked to check, in pairs, their third version.

The teacher will request the learners to put their letter third version in the box, and then will check the learners' written production: first by praising their progress. Then, the teacher will only point out the mistakes. After that, the letters will be given back to the students for changes or corrections.

Final version: With their third version in hand, the learners will write the final version of their advice letters by following the suggestions given by the teacher previously.

\section{APPENDIX 2}

Analysis of the reference text

\section{The letter: I'VE GOT A MAJOR CRUSH - BUT HE'S GOT A GIRLFRIEND!}

LEXY Writes...

Dear Betty, I have a crush on this popular guy in my school. He's so cute and funny. OK, so he gave me his phone number on the last day of school (he saw that a friend of mine wrote that I liked him). But the problem is that 1) I'm not really popular; 2) He has a girlfriend; 3) I never had classes with him, so he doesn't really know me; and 4) I'm scared of calling him, I think he'll make fun of me or something.

Please, can you help me? What should I do? Lexy

Source: http://www.beatboxbetty.com/dearbetty/dearbetty/dearbetty.htm

Accessed on: October 25, 2007. 


\section{ANALYSIS OF THE LEXY'S LET'TER}

\begin{tabular}{|c|c|c|}
\hline $\begin{array}{l}\text { Genre: Advice } \\
\text { letter }\end{array}$ & \multicolumn{2}{|c|}{$\begin{array}{l}\text { Text: "I'VE GOT A MAJOR CRUSH - BUT HE'S GOT A } \\
\text { GIRLFRIEND!” }\end{array}$} \\
\hline $\begin{array}{l}\text { Textual infra- } \\
\text { structure }\end{array}$ & $\begin{array}{l}\text { Global plan: } \\
\text { - Initial greeting: "Dear Betty" } \\
\text { - Presentation of the situation: the girl is in love / } \\
\text { she's got his phone number. } \\
\text {-Statement of the problem: she's not popular at } \\
\text { school / he's already got a girlfriend / she's afraid } \\
\text { of calling him. } \\
\text { - Asking for advice: she asks what she should do. } \\
\text { - Pseudonym: "Lexy" }\end{array}$ & $\begin{array}{l}\text { Type of } \\
\text { sequences: } \\
\text { Descriptive and } \\
\text { Explicative }\end{array}$ \\
\hline & \multicolumn{2}{|c|}{$\begin{array}{l}\text { Connection: } \\
\text { - The use of "so", ("so he gave me his phone number on the last day of } \\
\text { school") first to show sequence and second to show consequence ("I never } \\
\text { had classes with him, so he doesn't really know me and...") } \\
\text { Others: contrast (but) conjunction } \\
\text { Nominal cohesion: } \\
\text {-Anaphoric deitics: personal pronouns:(he/his/him, I/me/my/mine...), } \\
\text { demonstratives (this) } \\
\text { Verbal cohesion: } \\
\text { - The presence of the Simple Present Simple and the Past Tenses to describe } \\
\text { the situation and to present the problem. The use of modal verbs to ask for } \\
\text { advice (can you help me? / What should I do?) }\end{array}$} \\
\hline & \multicolumn{2}{|c|}{$\begin{array}{l}\text { Voices: } \\
\text { The author's letter: an adolescent girl who is in love (pseudonym: Lexy) and } \\
\text { an on-line adviser (Betty) } \\
\text { Modalizers: } \\
\text { - The use of the verb 'to be scared': ("I'm scared of calling him"). } \\
\text { Lexical choices: } \\
\text { "I'm not really popular" / "He has a girlfriend" - shows the author's values } \\
\text { and evaluation of the situation. } \\
\text { "I think he'll make fun of me or something" - this expression shows what } \\
\text { she is really scared of. }\end{array}$} \\
\hline
\end{tabular}

